\title{
FIXATION OF CARBON DIOXIDE BY PREIMPLANTATION RABBIT EMBRYOS IN VITRO
}

\author{
P. QUINN* AND R. G. WALES \\ Department of Veterinary Physiology, University of Sydney, \\ Sydney 2006, Australia
}

(Received 19th December 1972)

Summary. During the first 3 days of development of the rabbit embryo, carbon fixed from $\mathrm{CO}_{2}$ accumulated in the embryos and culture medium and increased as development proceeded.

Ultracellularly, incorporation of carbon into acid-soluble material accounted for 60 to $85 \%$ of the total fixed carbon, with most of the the remaining carbon entering the protein fraction. In the medium, most of the fixed carbon was found in the acid-soluble fraction. Although a similar proportion of embryos developed in either the presence or absence of exogenous energy substrates, the amount of fixed carbon accumulating in both the embryos and culture medium was greater when energy substrates were included in the medium. There was little difference between the amounts of carbon incorporated into embryos cultured in medium containing either glucose or pyruvate plus lactate. In these media, however, the accumulation of fixed carbon in the glucose medium was lower than that in the medium containing pyruvate and lactate. This difference was less marked at the later stages of embryonic development.

Aspartic and glutamic acids were the major compounds containing fixed carbon in the basic portion of the acid-soluble fraction of the embryos. Fixed carbon accumulating in the medium was found in lactate, malate, citrate, pyruvate and, to a lesser extent, acetate.

\section{INTRODUCTION}

The condensation of $\mathrm{CO}_{2}$ with pyruvate and its entry into the tricarboxylic acid (TCA) cycle as malate or oxaloacetate is an important process in the energy metabolism of the preimplantation mouse embryo (Quinn \& Wales, 1971). Although there has been no actual measurement of this process in the preimplantation rabbit embryo, Fridhandler (1968) concluded that, since there was no appreciable accumulation of carbon-1 of pyruvate in glutamate and aspartate in Day-6 rabbit blastocysts, the conversion of pyruvate to a 4carbon intermediate could not be a major pathway for its utilization.

\footnotetext{
* Present address: The Jackson Laboratory, Bar Harbor, Maine 04609, U.S.A.
} 
The pattern of energy metabolism in mouse and rabbit embryos appears to be similar. The oxidation of pyruvate and lactate is greater than that of glucose in both species (Brinster, 1969). Two-cell mouse embryos develop to the blastocyst stage in medium containing pyruvate or lactate and the addition of either of these substances to medium containing low levels of amino-nitrogen increases the proportion of two-cell rabbit embryos developing to the morula stage (Brinster, 1965a, 1970). In addition, the embryos of both species develop in bicarbonate-buffered medium (Brinster, 1963, 1970). From these similarities, one might expect to find that the fixation of $\mathrm{CO}_{2}$ occurs in the rabbit as well as the mouse embryo.

The incorporation of fixed carbon from ${ }^{14} \mathrm{C}$-labelled $\mathrm{CO}_{2}$ has been measured in cultured rabbit embryos during the first 3 days of preimplantation development. To assess the contributions of energy pools to metabolic turnover, the embryos were cultured in substrate-free medium or medium which contained either glucose or pyruvate plus lactate. Because of the technical difficulties encountered in culturing large embryos in the system used to measure the fixation of $\mathrm{CO}_{2}$, no investigations beyond the commencement of blastocoele formation in the rabbit embryo were attempted. The rôle of $\mathrm{CO}_{2}$ fixation might not be expected to change greatly at these later stages of development as studies of glucose metabolism in preimplantation rabbit embryos have indicated that during blastocyst expansion there is essentially only a quantitative change in metabolism in the embryo (Quinn \& Wales, 1973b).

\section{MATERIALS AND METHODS}

\section{Collection and culture of embryos}

For each replicate, 60 to 100 embryos were obtained from female rabbits of an albino laboratory strain which had been induced to superovulate as previously described (Quinn \& Wales, 1973b). Embryos collected on the day after induction of ovulation and insemination (Day 1) were at the one- and two-cell stage. Eight- to sixteen-cell stages and morulae were recovered from donors on Days 2 and 3, respectively.

The basic medium used was a modified Krebs-Ringer bicarbonate solution containing $1 \mathrm{mg}$ bovine serum albumin $/ \mathrm{ml}, 60 \mu \mathrm{g}$ penicillin $/ \mathrm{ml}$ and $50 \mu \mathrm{g}$ streptomycin $/ \mathrm{ml}$. When energy substrates were added to this medium, isotonicity was maintained by adjusting the $\mathrm{NaCl}$ content. Medium containing $25 \mathrm{~mm}$-DL-sodium lactate and $0.25 \mathrm{~mm}$-sodium pyruvate was used to flush the embryos from the reproductive tracts of the donor animals (Brinster, 1965b). The embryos were washed twice $(2 \mathrm{ml} /$ wash $)$ in substrate-free medium and then cultured for $24 \mathrm{hr}$ at $37^{\circ} \mathrm{C}$ in 20- $\mu$ l drops of medium (twenty embryos/drop) containing ${ }^{14} \mathrm{C}$-labelled $\mathrm{NaHCO}_{3}$ with a gas phase of $5 \%{ }^{14} \mathrm{CO}_{2}$ in air (Wales, Quinn \& Murdoch, 1969). The specific activity of the sodium bicarbonate varied between 6.5 and $12.0 \mu \mathrm{Ci} / \mu \mathrm{mol}$ in different experiments.

The embryos were cultured in substrate-free medium or in media which contained either $5.56 \mathrm{~mm}$-glucose or $0.5 \mathrm{~mm}$-sodium pyruvate plus $10 \mathrm{~mm}-\mathrm{DL}$ sodium lactate as substrate sources. The levels of pyruvate and lactate used are 
similar to those which have been found to be optimal for the growth and metabolism of the preimplantation rabbit embryo (Brinster, 1969, 1970; P. Quinn \& R. G. Wales, unpublished observations).

\section{Recovery of embryos and fractionation of samples}

After culture for $24 \mathrm{hr}$, embryos which had developed were removed from the drops of culture medium and collected by centrifugation (Wales \& Biggers, 1968). Embryos up to and including the morula stage were centrifuged through isotonic sucrose whereas non-radioactive medium was used during the collection of early blastocysts (Wales \& Whittingham, 1970). The total amount of $\mathrm{CO}_{2}$ fixed in developing embryos was estimated, using a sample of three to five embryos. The remaining embryos were saved for extraction of metabolic products. The embryos were removed from the broken tip of the centrifuge tube, acidified with $0.1 \mathrm{ml}$ of $2 \mathrm{~N}-\mathrm{H}_{2} \mathrm{SO}_{4}$ and left overnight in a sealed beaker which contained $\mathrm{NaOH}$ to absorb any $\mathrm{CO}_{2}$ liberated by the acidification. The samples were then neutralized with $0.1 \mathrm{ml}$ of $2 \mathrm{~N}-\mathrm{NaOH}$ and stored at $-20^{\circ} \mathrm{C}$ until extracted.

Aliquots of the media in which the embryos had been cultured were acidified and treated in a similar fashion to the embryos to remove any $\mathrm{CO}_{2}$ which had not reacted. After neutralization, the amount of radioactivity in a 20- to 25- $\mu \mathrm{l}$ sample was assayed to assess the total incorporation of fixed carbon. The remainder of this medium was saved for fractionation. In an initial trial, oneand two-cell embryos which had been killed by incubation for $30 \mathrm{~min}$ in substrate-free medium containing $10 \%$ formalin had no significant uptake of label or fixation of label into the medium after incubation at $37^{\circ} \mathrm{C}$ for $24 \mathrm{hr}$ in radioactive bicarbonate. Therefore, control samples of medium in which no embryos had been cultured were used to correct for residual background radioactivity in the samples of culture medium.

Before fractionation of embryos and media, a 50- $\mu$ l aliquot of sheep serum was added as carrier. The samples were then fractionated into acid-soluble, protein and lipid fractions by the method described by Wales \& Whittingham (1970). Cold $2.5 \%(\mathrm{v} / \mathrm{v})$ perchloric acid was used to extract the acid-soluble fraction and lipids were removed from the acid-insoluble precipitate ('protein' fraction) with chloroform: ether $(1: 1, \mathrm{v} / \mathrm{v})$. The acid-soluble fraction of all samples was further divided into acidic, basic and neutral portions by passage through columns of ion-exchange resins (see Wales \& Whittingham, 1970). To obtain sufficient material for further identification of labelled compounds, replicate samples of the acid-soluble fraction of medium from each treatment were pooled and the carboxylic acids separated by liquid-liquid partition chromatography (O'Shea \& Wales, 1968). Replicate samples of the acidsoluble fraction of embryos from similar treatments were also pooled and the basic compounds, recovered by ion-exchange chromatography, were differentiated by paper chromatography using water-saturated phenol as the developing solvent (see Quinn \& Wales, 1971). Identification of the acidic compounds in the acid-soluble fractions of the embryos was not attempted.

Radioactivity in all samples was assayed by liquid scintillation techniques using $5 \mathrm{ml}$ Triton X100-toluene $(1: 2 \mathrm{v} / \mathrm{v})$ containing $0.4 \%(\mathrm{w} / \mathrm{v})$ 2,5-diphenyl- 
oxazole and $0.01 \%(\mathrm{w} / \mathrm{v}) \quad 1,4$ bis(4-methyl-5-phenyloxazol-2-yl) benzene for each $0.4 \mathrm{ml}$ of aqueous sample.

\section{Statistical analysis}

All data relating to the accumulation of fixed carbon in the embryos and media were transformed to logarithms before analysis and the significance of the results was assessed by analysis of variance.

\section{RESULTS}

The development of rabbit embryos during culture for $24 \mathrm{hr}$ in the presence of radioactive bicarbonate is given in Table 1. Embryos collected from donors on Day 1 developed from the one- and two-cell stage to the four- and eight-cell stage. Day-2 embryos developed from the eight- to sixteen-cell stage into

Table 1. Fixation of carbon dioxide by rabbit embryos cultured for $24 \mathrm{hr}$ in media containing various energy substrates

\begin{tabular}{|c|c|c|c|c|c|c|}
\hline \multirow{3}{*}{$\begin{array}{c}\text { Period of } \\
\text { development }\end{array}$} & \multirow{3}{*}{$\begin{array}{c}\text { Energy } \\
\text { substrates } \\
\text { in medium }\end{array}$} & \multirow{3}{*}{$\begin{array}{l}\% \text { embryos } \\
\text { developed }\end{array}$} & \multicolumn{4}{|c|}{ Carbon incorporated from $\mathrm{CO}_{2}$ (pg atoms/embryo) } \\
\hline & & & \multicolumn{2}{|c|}{ Total incorporation } & \multirow{2}{*}{$\begin{array}{c}\text { Acid-soluble } \\
\text { fraction }\end{array}$} & \multirow{2}{*}{$\begin{array}{l}\text { Protein } \\
\text { fraction }\end{array}$} \\
\hline & & & Estimate $A^{*}$ & Estimate $B \dagger$ & & \\
\hline $\begin{array}{l}1-\text { and 2-cell to } \\
4-\text { and 8-cell }\end{array}$ & $\begin{array}{l}\text { None } \\
\text { Glucose } \\
\text { Pyruvate+ lactate }\end{array}$ & $\begin{array}{l}82 \pm 6 \\
82 \pm 10 \\
85 \pm 3\end{array}$ & $\begin{array}{l}0.48 \pm 0.05 \\
0.99 \pm 0.28 \\
1 \cdot 20 \pm 0 \cdot 18\end{array}$ & $\begin{array}{l}0.85 \pm 0.04 \\
1 \cdot 21 \pm 0.22 \\
1.46 \pm 0.20\end{array}$ & $\begin{array}{l}0.53 \pm 0.08 \\
0.86 \pm 0.14 \\
1 \cdot 03 \pm 0.13\end{array}$ & $\begin{array}{l}0.31 \pm 0.11 \\
0.35 \pm 0.09 \\
0.43 \pm 0.07\end{array}$ \\
\hline $\begin{array}{l}\text { 8- and 16-ceil to } \\
\text { morula }\end{array}$ & $\begin{array}{l}\text { None } \\
\text { Glucose } \\
\text { Pyruvate + lactate }\end{array}$ & $\begin{array}{l}94 \pm 1 \\
95 \pm 1 \\
96 \pm 1\end{array}$ & $\begin{array}{l}0.53 \pm 0.18 \\
1.91 \pm 0.30 \\
1.55 \pm 0.23\end{array}$ & $\begin{array}{l}0.84 \pm 0.26 \\
2 \cdot 07 \pm 0.51 \\
1.87 \pm 0.38\end{array}$ & $\begin{array}{l}0.70 \pm 0.26 \\
1 \cdot 76 \pm 0.48 \\
1 \cdot 53 \pm 0.37\end{array}$ & $\begin{array}{l}0.14 \pm 0.01 \\
0.31 \pm 0.06 \\
0.32 \pm 0.03\end{array}$ \\
\hline $\begin{array}{l}\text { Morula to } \\
\text { early blastocyst }\end{array}$ & $\begin{array}{l}\text { None } \\
\text { Glucose } \\
\text { Pyruvate+ lactate }\end{array}$ & $\begin{array}{l}87 \pm 5 \\
81 \pm 4 \\
78 \pm 6\end{array}$ & $\begin{array}{l}3 \cdot 86 \pm 1 \cdot 25 \\
8 \cdot 24 \pm 1 \cdot 52 \\
6 \cdot 35 \pm 1 \cdot 05\end{array}$ & $\begin{array}{l}4.02 \pm 0.68 \\
7 \cdot 64 \pm 1 \cdot 61 \\
5 \cdot 66 \pm 0.74\end{array}$ & $\begin{array}{l}3.04 \pm 0.42 \\
5 \cdot 71 \pm 1.38 \\
4.33 \pm 0.79\end{array}$ & $\begin{array}{l}0.97 \pm 0.26 \\
1.92 \pm 0.24 \\
1.32 \pm 0.25\end{array}$ \\
\hline
\end{tabular}

Mean values of three replicates \pm S.E.M. at each stage of development.

* Estimate of total incorporation from five unfractionated embryos.

$\dagger$ Estimate of total incorporation from sum of fractionated carbon in extracted embryos.

morulae and morulae collected on Day 3 developed to the early blastocyst stage. The supply of exogenous energy substrates had no effect on the numbers of embryos developing and 80 to $95 \%$ of all embryos developed during culture. The incorporation of carbon from ${ }^{14} \mathrm{C}$-labelled $\mathrm{NaHCO}_{3}$ and ${ }^{14} \mathrm{CO}_{2}$ into the embryos is also given in Table 1. The estimate of total carbon incorporated into the embryos from a sample of unfractionated embryos (Estimate A of Table 1) was in good agreement $(86 \pm 5 \%)$ with the estimate based on the sum of fractionated carbon in the extracted embryos (Estimate B). The embryos cultured in media containing exogenous energy substrates incorporated significantly $(P<0.01)$ more fixed carbon than those cultured in substratefree medium. A significant $(P<0 \cdot 01)$ linear increase in the fixation into the embryos occurred as development progressed, but the rate of this increase depended on the provision of an adequate source of energy. Thus, the total incorporation of fixed carbon into embryos cultured in substrate-free medium 
did not differ appreciably between Day 1 and Day 2 of development, whereas a substantial increase in incorporation occurred over this period in embryos cultured in the presence of energy substrates. Incorporation of fixed carbon into Day-3 embryos cultured in all three media was three to five times greater than that into cultured Day-2 embryos.

Between 60 and $85 \%$ of the total carbon accumulating in the embryos was present in the acid-soluble fraction. The protein fraction was the other major component of the embryos in which fixed carbon accumulated. Embryos cultured in substrate-free medium incorporated less fixed carbon into both of these fractions than those cultured in medium containing energy substrates. In general, the amount of carbon incorporated into the protein fraction of the embryos was slightly lower in Day-2 than Day-1 embryos but increased four- to sevenfold between Days 2 and 3. Incorporation into lipids was small, accounting for $1 \%$ or less of the total carbon fixed into the embryos and there were no significant changes over the stages of development studied.

Table 2. Fixation of carbon dioxide into the acidic, basic and neutral compounds of the acid-soluble fraction of rabbit embryos cultured for $24 \mathrm{hr}$ in various media

\begin{tabular}{|c|c|c|c|c|}
\hline \multirow[b]{2}{*}{ Period of development } & \multirow[b]{2}{*}{$\begin{array}{l}\text { Energy substrates } \\
\text { in medium }\end{array}$} & \multicolumn{3}{|c|}{ Carbon incorporated from $\mathrm{CO}_{2}$ (pg atoms/embryo) } \\
\hline & & $\begin{array}{c}\text { Acidic } \\
\text { compounds }\end{array}$ & $\begin{array}{c}\text { Basic } \\
\text { compounds }\end{array}$ & $\begin{array}{c}\text { Neutral } \\
\text { compounds }\end{array}$ \\
\hline $\begin{array}{l}\text { 1- and 2-cell to } \\
4-\text { and } 8 \text {-cell }\end{array}$ & $\begin{array}{l}\text { None } \\
\text { Glucose } \\
\text { Pyruvate+ lactate }\end{array}$ & $\begin{array}{l}0.17 \pm 0.04(32) \\
0.21 \pm 0.02(24) \\
0.32 \pm 0.07(31)\end{array}$ & $\begin{array}{l}0.31 \pm 0.11(59) \\
0.58 \pm 0 \cdot 13(67) \\
0.56 \pm 0.11(54)\end{array}$ & $\begin{array}{l}0.05 \pm 0.02(9) \\
0.07 \pm 0.02(9) \\
0.15 \pm 0.05(14)\end{array}$ \\
\hline $\begin{array}{l}\text { 8- and 16-cell to } \\
\text { morula }\end{array}$ & $\begin{array}{l}\text { None } \\
\text { Glucose } \\
\text { Pyruvate+lactate }\end{array}$ & $\begin{array}{l}0 \cdot 25 \pm 0 \cdot 13(36) \\
0 \cdot 62 \pm 0 \cdot 14(35) \\
0 \cdot 78 \pm 0 \cdot 14(51)\end{array}$ & $\begin{array}{l}0.29 \pm 0.08(42) \\
0.96 \pm 0.41(55) \\
0.63 \pm 0.21(41)\end{array}$ & $\begin{array}{l}0.15 \pm 0.07(22) \\
0.18 \pm 0.03(10) \\
0.13 \pm 0.06(8)\end{array}$ \\
\hline $\begin{array}{l}\text { Morula to } \\
\text { early blastocyst }\end{array}$ & $\begin{array}{l}\text { None } \\
\text { Glucose } \\
\text { Pyruvate+lactate }\end{array}$ & $\begin{array}{l}1.05 \pm 0.13(35) \\
1.76 \pm 0.51(31) \\
1.67 \pm 0.27(39)\end{array}$ & $\begin{array}{l}1.65 \pm 0.38(54) \\
3.33 \pm 1.13(58) \\
2.44 \pm 1.04(56)\end{array}$ & $\begin{array}{l}0.33 \pm 0.13(11) \\
0.62 \pm 0.20(11) \\
0.22 \pm 0.11(5)\end{array}$ \\
\hline
\end{tabular}

Mean values \pm S.E.M. for three replicates at each stage of development are given with the percentage of the acid-soluble fraction shown in parentheses.

The distribution of fixed carbon in the acid-soluble fraction of the embryos is given in Table 2. Between 40 to $65 \%$ and 25 to $50 \%$ of the acid-soluble carbon was present in basic and acidic compounds, respectively, and similar trends to those occurring for incorporation into the acid-soluble fraction were evident with these compounds. The neutral portion of the acid-soluble fraction accounted for only 5 to $20 \%$ of the acid-soluble carbon fixed during the incubation. As with the basic and acidic portions, the amount of acid-soluble carbon accumulating in the neutral compounds increased as the age of the embryos increased.

A tentative identification of the labelled amino acids present in the basic portion of the acid-soluble fraction of the embryos is given in Table 3. Overall, quantitative recovery $(100 \pm 11 \%)$ of radioactivity applied to the chromatograms was achieved and peaks with $R_{\mathrm{F}}$ values corresponding to aspartic and glutamic acids accounted for the majority of the radioactivity in the fraction. Alanine 
Table 3. Incorporation of fixed carbon into the amino acids of the acid-soluble fraction of rabbit embryos cultured for $24 \mathrm{hr}$ in media containing various energy substrates and radioactive bicarbonate and carbon dioxide

\begin{tabular}{|c|c|c|c|c|}
\hline \multirow{2}{*}{ Period of development } & \multirow{2}{*}{$\begin{array}{l}\text { Energy substrates } \\
\text { in medium }\end{array}$} & \multicolumn{3}{|c|}{$\begin{array}{c}\text { Carbon incorporated from } \mathrm{CO}_{2} \\
\text { (pg atomslembryo) }\end{array}$} \\
\hline & & Aspartate & Glutamate & Alanine \\
\hline $\begin{array}{l}1-\text { and } 2 \text {-cell to } \\
4-\text { and } 8 \text {-cell }\end{array}$ & $\begin{array}{l}\text { None } \\
\text { Glucose } \\
\text { Pyruvate+lactate }\end{array}$ & $\begin{array}{l}0.13(41) \\
0.54(94) \\
0.30(54)\end{array}$ & $\begin{array}{l}0.02(5) \\
0.01(2) \\
0.09(17)\end{array}$ & $\begin{array}{r}<0.01(2) \\
<0.01(1) \\
0.02(3)\end{array}$ \\
\hline $\begin{array}{l}8 \text { - and 16-cell to } \\
\text { morula }\end{array}$ & $\begin{array}{l}\text { None } \\
\text { Glucose } \\
\text { Pyruvate + lactate }\end{array}$ & $\begin{array}{l}0.18(60) \\
0.70(72) \\
0.38(60)\end{array}$ & $\begin{array}{l}0.07(24) \\
0.25(26) \\
0.15(24)\end{array}$ & $\begin{array}{l}0 \\
0.02(2) \\
0.01(2)\end{array}$ \\
\hline $\begin{array}{l}\text { Morula to } \\
\text { early blastocyst }\end{array}$ & $\begin{array}{l}\text { None } \\
\text { Glucose } \\
\text { Pyruvate+ lactate }\end{array}$ & $\begin{array}{l}1 \cdot 00(60) \\
2 \cdot 31(69) \\
1 \cdot 35(56)\end{array}$ & $\begin{array}{l}0.45(27) \\
1.00(30) \\
0.62(26)\end{array}$ & $\begin{array}{l}0.12(7) \\
0.02(1) \\
0 \cdot 24(10)\end{array}$ \\
\hline
\end{tabular}

Values for three pooled replicates within each treatment are given. The percentage of the total basic acid-soluble compounds that each compound represents is shown in parentheses.

represented a small proportion of the carbon fixed into the basic compounds of the embryos.

The accumulation of fixed carbon in the culture medium is given in Table 4 . The estimates of total incorporation based on aliquots of unfractionated media (Estimate A of Table 4) were in good agreement $(100 \pm 2 \%)$ with the estimates based on the sum of fractionated carbon in the extracted samples (Estimate B). Nearly all of the fixed carbon in the culture medium was present in the acid-soluble fraction. There was a significant $(P<0.01)$ linear increase

Table 4. Accumulation of fixed carbon in the medium during culture of rabbit embryos for $24 \mathrm{hr}$ in the presence of various energy substrates and radioactive bicarbonate and carbon dioxide

\begin{tabular}{|c|c|c|c|c|}
\hline \multirow{3}{*}{ Period of development } & \multirow{3}{*}{$\begin{array}{l}\text { Energy substrates } \\
\text { in medium }\end{array}$} & \multicolumn{3}{|c|}{$\begin{array}{c}\text { Carbon incorporated from } \\
(\text { pg atoms/embryo })\end{array}$} \\
\hline & & \multicolumn{2}{|c|}{ Total incorporation } & \multirow{2}{*}{$\begin{array}{l}\text { Acid-soluble } \\
\text { fraction }\end{array}$} \\
\hline & & Estimate $A^{*}$ & Estimate $B \dagger$ & \\
\hline $\begin{array}{l}\text { 1- and 2-cell to } \\
\text { 4- and 8-cell }\end{array}$ & $\begin{array}{l}\text { None } \\
\text { Glucose } \\
\text { Pyruvate+lactate }\end{array}$ & $\begin{array}{l}0.29 \pm 0.11 \\
0.48 \pm 0.13 \\
2 \cdot 17 \pm 0.73\end{array}$ & $\begin{array}{l}0.34 \pm 0.16 \\
0.51 \pm 0.17 \\
2 \cdot 21 \pm 0.79\end{array}$ & $\begin{array}{l}0.34 \pm 0.16 \\
0.51 \pm 0.17 \\
2 \cdot 21 \pm 0.78\end{array}$ \\
\hline $\begin{array}{l}\text { 8- and 16-cell to } \\
\text { morula }\end{array}$ & $\begin{array}{l}\text { None } \\
\text { Glucose } \\
\text { Pyruvate+ lactate }\end{array}$ & $\begin{array}{l}0.44 \pm 0.09 \\
0.98 \pm 0.15 \\
2.22 \pm 0.66\end{array}$ & $\begin{array}{l}0.48 \pm 0.09 \\
0.94 \pm 0.15 \\
2.04 \pm 0.52\end{array}$ & $\begin{array}{l}0.46 \pm 0.08 \\
0.93 \pm 0.16 \\
2.00 \pm 0.53\end{array}$ \\
\hline $\begin{array}{l}\text { Morula to } \\
\text { early blastocyst }\end{array}$ & $\begin{array}{l}\text { None } \\
\text { Glucose } \\
\text { Pyruvate + lactate }\end{array}$ & $\begin{array}{r}3 \cdot 51 \pm 0.73 \\
9.95 \pm 4 \cdot 22 \\
12 \cdot 44 \pm 2 \cdot 77\end{array}$ & $\begin{array}{r}3 \cdot 36 \pm 0 \cdot 72 \\
9 \cdot 56 \pm 2 \cdot 87 \\
12 \cdot 17 \pm 2 \cdot 52\end{array}$ & $\begin{array}{r}3 \cdot 21 \pm 0.66 \\
9 \cdot 40 \pm 2 \cdot 86 \\
12 \cdot 07 \pm 2 \cdot 52\end{array}$ \\
\hline
\end{tabular}

Mean values of three replicates \pm S.E.M. are given.

* Estimate of total incorporation from an aliquot of unfractionated medium.

$\uparrow$ Estimate of total incorporation from sum of fractionated carbon in extracted medium. 
Table 5. Carbon fixed into the acidic, basic and neutral compounds of the acid-soluble fraction of media in which rabbit embryos were cultured for $24 \mathrm{hr}$ in the presence of various energy substrates and radioactive bicarbonate and carbon dioxide

\begin{tabular}{|c|c|c|c|c|}
\hline \multirow[b]{2}{*}{ Period of development } & \multirow{2}{*}{$\begin{array}{l}\text { Energy substrates } \\
\text { in medium }\end{array}$} & \multicolumn{3}{|c|}{ Carbon incorporated from $\mathrm{CO}_{2}$ (pg atoms/embryo) } \\
\hline & & $\begin{array}{l}\text { Acidic } \\
\text { compounds }\end{array}$ & $\begin{array}{c}\text { Basic } \\
\text { compounds }\end{array}$ & $\begin{array}{c}\text { Neutral } \\
\text { compounds }\end{array}$ \\
\hline $\begin{array}{l}\text { 1- and 2-cell to } \\
\text { 4- and 8-cell }\end{array}$ & $\begin{array}{l}\text { None } \\
\text { Glucose } \\
\text { Pyruvate + lactate }\end{array}$ & $\begin{array}{l}0.18 \pm 0.07(53) \\
0.15 \pm 0.07(30) \\
1.50 \pm 0.20(68)\end{array}$ & $\begin{array}{l}0.13 \pm 0.08(39) \\
0.33 \pm 0.07(64) \\
0.71 \pm 0.17(32)\end{array}$ & $\begin{array}{l}0.03 \pm 0.02(8) \\
0.03 \pm 0.03(6)\end{array}$ \\
\hline $\begin{array}{l}\text { 8- and } 16 \text {-cell to } \\
\text { morula }\end{array}$ & $\begin{array}{l}\text { None } \\
\text { Glucose } \\
\text { Pyruvate + Iactate }\end{array}$ & $\begin{array}{l}0.21 \pm 0.03(46) \\
0.59 \pm 0.12(63) \\
1.31 \pm 0.36(66)\end{array}$ & $\begin{array}{l}0.19 \pm 0.07(41) \\
0.34 \pm 0.07(37) \\
0.54 \pm 0.15(27)\end{array}$ & $\begin{array}{l}0.06 \pm 0.03(13) \\
0.01 \pm 0.01(1) \\
0.14 \pm 0.07(7)\end{array}$ \\
\hline $\begin{array}{l}\text { Morula to } \\
\text { early blastocyst }\end{array}$ & $\begin{array}{l}\text { None } \\
\text { Glucose } \\
\text { Pyruvate + lactate }\end{array}$ & $\begin{array}{l}1 \cdot 31 \pm 0.26(41) \\
7.05 \pm 1 \cdot 88(75) \\
9 \cdot 17 \pm 2 \cdot 22(76)\end{array}$ & $\begin{array}{l}1 \cdot 20 \pm 0.47(37) \\
1 \cdot 32 \pm 0.30(14) \\
2 \cdot 09 \pm 0.20(17)\end{array}$ & $\begin{array}{l}0.69 \pm 0.08(22) \\
1.03 \pm 0.72(11) \\
0.81 \pm 0.22(7)\end{array}$ \\
\hline
\end{tabular}

Mean values \pm S.E.M. of three replicates at each stage of development with percentage of acid-soluble fraction are shown in parentheses.

in the amount of carbon accumulating as the age of the embryos increased. Significantly $(P<0.01)$ more fixed carbon accumulated in the media containing energy compounds than in substrate-free medium. Accumulation in medium containing pyruvate and lactate was significantly $(P<0.01)$ greater than that in the medium containing glucose. The relative difference in the incorporation into these media became less as embryonic development progressed.

Estimates of the accumulation of carbon from $\mathrm{CO}_{2}$ in the acid-insoluble protein fraction of the media were also attempted. Day-1 embryos did not accumulate carbon from $\mathrm{CO}_{2}$ in this fraction. In some of the media in which Day-2 embryos were cultured, counts of up to $20 \%$ above background were measured in this fraction. The variation between samples was such that, overall, the counts were not significantly greater than background. When Day-3

Table 6. Carbon accumulated in carboxylic acids of media in which rabbit embryos were cultured for $24 \mathrm{hr}$ in presence of various energy substrates and radioactive bicarbonate and carbon dioxide

\begin{tabular}{|c|c|c|c|c|c|c|}
\hline \multirow{2}{*}{ Period of development } & \multirow{2}{*}{$\begin{array}{l}\text { Energy substrates } \\
\text { in medium }\end{array}$} & \multicolumn{5}{|c|}{ Carbon incorporated from $\mathrm{CO}_{2}$ ( $p \mathrm{~g}$ atoms/embryo) } \\
\hline & & Acetate & Pyruvate & Lactate & Malate & Citrate \\
\hline $\begin{array}{l}1-\text { and } 2-c e l l ~ t o ~ \\
4-\text { and } 8 \text {-cell }\end{array}$ & $\begin{array}{l}\text { None } \\
\text { Glucose } \\
\text { Pyruvate + lactate }\end{array}$ & $\begin{array}{l}0.0 \\
0.02(4) \\
0.03(1)\end{array}$ & $\begin{array}{l}0.0 \\
0.03(5) \\
0.11(5)\end{array}$ & $\begin{array}{l}0.0 \\
0.03(6) \\
0.61(28)\end{array}$ & $\begin{array}{l}0.0 \\
0.12(25) \\
0.05(2)\end{array}$ & $\begin{array}{l}0.0 \\
0.0 \\
0.14(6)\end{array}$ \\
\hline $\begin{array}{l}\text { 8- and 16-cell to } \\
\text { morula }\end{array}$ & $\begin{array}{l}\text { None } \\
\text { Glucose } \\
\text { Pyruvate + lactate }\end{array}$ & $\begin{array}{l}0.03(7) \\
0.06(6) \\
0.10(5)\end{array}$ & $\begin{array}{l}0.07(15) \\
0.07(7) \\
0.15(7)\end{array}$ & $\begin{array}{l}0.03(7) \\
0.11(12) \\
0.70(35)\end{array}$ & $\begin{array}{l}{ }^{*} \\
0 \cdot 12(12) \\
0 \cdot 16(8)\end{array}$ & $\begin{array}{c}* \\
0.08(9) \\
0.07(4)\end{array}$ \\
\hline $\begin{array}{l}\text { Morula to } \\
\text { early blastocyst }\end{array}$ & $\begin{array}{l}\text { None } \\
\text { Glucose } \\
\text { Pyruvate+lactate }\end{array}$ & $\begin{array}{l}0.22(7) \\
0.35(4) \\
0.10(1)\end{array}$ & $\begin{array}{l}0.19(6) \\
0.53(6) \\
1.23(10)\end{array}$ & $\begin{array}{l}0.55(17) \\
2.49(27) \\
4 \cdot 19(35)\end{array}$ & $\begin{array}{l}0.83(26) \\
1.87(20) \\
2.08(17)\end{array}$ & $\begin{array}{l}0.34(10) \\
1.18(13) \\
1.56(13)\end{array}$ \\
\hline
\end{tabular}

Values for three pooled replicates within each treatment are given. The percentage of the total acid-soluble fraction that each compound represents is shown in parentheses.

* Sample lost. 
embryos were cultured, however, an average of $63 \%$ more counts than background accumulated in the protein fraction of the media. This gave values of $0 \cdot 16 \pm 0.07,0 \cdot 16 \pm 0.02$ and $0.10 \pm 0.01 \mathrm{pg}$ atoms/embryo for the accumulation of fixed carbon in the protein fraction of substrate-free medium, glucose medium and pyruvate plus lactate medium, respectively. These values represent only $5 \%$ or less of the total carbon accumulating in the media during culture of Day-3 embryos. There was no accumulation of label in the lipid fraction of the media at any stage of development.

The distribution of carbon fixed in the acid-soluble fraction of media is given in Table 5. The amount of fixed carbon accumulating in the acidic, basic and neutral compounds increased with embryonic development. Most of this increase during culture of Day-3 embryos was due to incorporation of carbon into the acidic compounds. Large differences in the accumulation of carbon in the acidic and basic compounds were found between substrate-free medium and media containing energy substrates. Incorporation into the neutral compounds represented $20 \%$ or less of the total carbon accumulated and there were no overall significant differences between the different media in the fixation of $\mathrm{CO}_{2}$ into these neutral compounds.

The acid-soluble fractions of pooled replicates of culture media were chromatographed on columns of silicic acid to separate and identify carboxylic acids. The results are given in Table 6. Although more than half of the acidsoluble carbon fixed into substrate-free medium following culture of one- and two-cell embryos was acidic in nature (Table 5), labelled carboxylic acids could not be detected in this medium. In other media analysed, the percentage of acid-soluble carbon accumulating in the carboxylic acids amounted to $104 \pm 12 \%$ of the label designated as acidic after separation by ion-exchange resins. In most of these media, lactate was the major acid identified while pyruvate comprised 5 to $15 \%$ of the labelled acid-soluble material. At all stages of development, the accumulation of fixed carbon in both lactate and pyruvate was greater in medium containing lactate and pyruvate than in the other media. Labelled malate and citrate were also present in most media, the amounts increasing when Day-3 embryos were cultured. A small amount of radioactivity having a chromatographic mobility equivalent to acetate was also detected in the extracts of the media.

\section{DISCUSSION}

The results obtained in this study demonstrate that the fixation of carbon dioxide is an active metabolic process in the rabbit embryo during the first 3 days of preimplantation development. Fridhandler (1968) has suggested that the fixation reaction does not play a very important rôle in the metabolism of the Day-6 rabbit blastocyst but his use of a phosphate-buffered medium with air as the gas phase may have been unfavourable for the fixation of $\mathrm{CO}_{2}$. A non-carboxylic buffered medium with air as the gas phase favours the reversal of the reactions of $\mathrm{CO}_{2}$ fixation resulting in the decarboxylation of intermediates such as oxaloacetate (see Paul, 1965). The concentration of bicarbonate found in rabbit oviduct secretions (David, Brackett, Garcia \& Mastroianni, 
1969 ) is similar to that used in modified Krebs-Ringer bicarbonate medium for the culture of mouse and rabbit embryos (Brinster, 1963, 1970). This would suggest that the fixation of $\mathrm{CO}_{2}$ could operate as well in vivo as it does in vitro in both the mouse and rabbit embryo and, as a result, benefit the energy metabolism of these embryos by maintaining the levels of intermediates in the TCA cycle during development.

The two-cell rabbit embryo does not require exogenous energy substrates to develop to the morula stage in vitro (Brinster, 1970) whereas the mouse embryo cannot accomplish this until the eight-cell stage is reached (Brinster \& Thomson, 1966; Wales \& Whittingham, 1973). Thus, the rabbit embryo is capable either of relying more on endogenous reserves or of utilizing the amino-nitrogen in the medium more effectively than the mouse embryo. Either of these processes would lessen the dependence of the rabbit embryo on $\mathrm{CO}_{2}$ fixation for the formation of TCA cycle intermediates. Although the rabbit embryo is approximately three times the size of the mouse embryo before the blastocyst stage (Brinster, 1968a), the amount of fixed carbon accumulating from $\mathrm{CO}_{2}$ during culture in media containing pyruvate and lactate is approximately the same, at similar stages of development (Quinn \& Wales, 1971). This observation also suggests that the rabbit embryo relies less on the fixation of $\mathrm{CO}_{2}$ than does the mouse embryo.

The accumulation of fixed carbon from $\mathrm{CO}_{2}$ into the amino acids, aspartate and glutamate, is similar to that which occurs in the mouse embryo (Quinn \& Wales, 1971). The relatively constant rate of accumulation of fixed carbon in these amino acids during the first 2 days of development is reflected in the rate of accumulation into the protein fraction of the embryos. After the morula stage, accumulation in both the amino acids and the protein fraction of the embryos increases several-fold over that at the preceding stages of development. By the fractionation procedures used in the present study, the protein fraction would also include macromolecules such as RNA and DNA. Manes (1969) and Manes \& Daniel (1969), using the incorporation of labelled nucleosides and amino acids, report that during development of the rabbit embryo, the synthesis of RNA and DNA remains relatively constant during the first 2 days and then begins to accelerate just before blastocyst formation. This is followed some $35 \mathrm{hr}$ later by an acceleration of protein synthesis. This pattern of macromolecular synthesis is similar to that found in the present study.

Even though a similar proportion of rabbit embryos develop in either substrate-free medium or media containing exogenous energy substrates, the amount of fixed carbon accumulating in both the embryos and culture medium is greater when energy substrates are present. This may be due to an increased metabolic turnover in the embryo in the presence of exogenous energy substrates, as suggested by Brinster (1970). Another likely explanation for the increased amount of $\mathrm{CO}_{2}$ fixed by the embryo in the presence of exogenous energy substrates is the trapping of radioactive compounds in unlabelled metabolic pools. Such a process could account for the high proportion of fixed carbon accumulated in medium containing pyruvate and lactate.

The accumulation of fixed carbon from $\mathrm{CO}_{2}$ in acetate and pyruvate in the medium during culture of the rabbit but not the mouse embryo (Quinn \& 
Wales, 1971) may reflect the higher levels of lactate dehydrogenase (E.C.1.1.1.27) in the mouse as compared to the rabbit embryo (Brinster, 1968b). This would tend to divert more carbon into lactate than either pyruvate or acetate in the mouse embryo. The increasing amount of fixed carbon found in both malate and citrate as development of the rabbit embryo progresses is similar to the situation found in the mouse embryo (Quinn \& Wales, 1971) and suggests that the activity of the TGA cycle increases as embryonic development proceeds. The ratio of ATP to ADP in the rabbit embryo decreases with increasing embryonic development (Brooks \& Lutwak-Mann, 1971; P. Quinn and R. G. Wales, unpublished data). As suggested for the mouse embryo (Quinn \& Wales, 1973a), this probably also indicates an increase in the activity of the TCA cycle in the rabbit embryo as development of the embryo progresses.

The accumulation of carbon from $\mathrm{CO}_{2}$ in the protein fraction of the media in which Day-3 embryos were cultured may be due to the accumulation of labelled macromolecules in the blastocoele fluid of these embryos and subsequent diffusion of these compounds into the culture medium.

\section{AGKNOWLEDGMENTS}

The authors are indebted to Professor G. W. Emmens for interest and criticism. The work was aided by a grant from the Australian Research Grants Committee. One of us (P.Q.) was supported by an Australian Wool Board Post-Graduate Studentship.

\section{REFERENGES}

Brinster, R. L. (1963) A method for in vitro cultivation of mouse ova from two-cell to blastocyst. Expl Cell Res. 32, 205.

Brinster, R. L. (1965a) Studies on the development of mouse embryos in vitro. II. The effect of energy source. 7. $\exp$. Zool. 158, 59.

BrINSTER, R. L. (1965b) Studies on the development of mouse embryos in vitro. IV. Interaction of energy sources. J. Reprod. Fert. 10, 227.

Brinster, R. L. (1968a) Garbon dioxide production from glucose by the preimplantation rabbit embryo. Expl Cell Res. 51, 330.

Brinster, R. L. (1968b) Lactate dehydrogenase activity in the oocytes of mammals. F. Reprod. Fert. 17, 139.

BRINSTER, R. L. (1969) Radioactive carbon dioxide production from pyruvate and lactate by the preimplantation rabbit embryo. Expl Cell Res. 54, 205.

Brinster, R. L. (1970) Culture of two-cell rabbit embryos to morulae. J. Reprod. Fert. $21,17$.

Brinster, R. L. \& Thomson, J. L. (1966) Development of eight-cell mouse embryos in vitro. Expl Cell Res. 42, 308.

Brooks, D. E. \& Lutwak-ManN, G. (1971) Content of ATP and ADP in rabbit blastocysts. Nature, Lond. 220, 202.

David, A., Brackett, B. G., Gargia, C.-R. \& Mastrolanni, L. (1969) Composition of rabbit oviduct fluid in ligated segments of the Fallopian tube. J. Reprod. Fert. 19, 285.

Fridhandler, L. (1968) Intermediary metabolic pathways in preimplantation rabbit blastocysts. Fert. Steril. 19, 424.

Manes, C. (1969) Nucleic acid synthesis in preimplantation rabbit embryos. I. Quantitative aspects, relationship to early morphogenesis and protein synthesis. $\mathcal{F}$. exp. Zool. 172, 303.

Manes, C. \& Daniel, J. C. (1969) Quantitative and qualitative aspects of protein synthesis in the preimplantation rabbit embryo. Expl Cell Res. 55, 261.

O'Shea, T. \& Wales, R. G. (1968) Metabolism of $\left[1-{ }^{14} \mathrm{G}\right]$ sodium lactate and $\left[2-{ }^{14} \mathrm{C}\right]$ sodium lactate by ram spermatozoa. J. Reprod. Fert. 15, 337.

Paur, J. (1965) Carbohydrate and energy metabolism. In: Cells and Tissues in Culture-Methods, Biology and Physiology, Vol. 1, p. 239. Ed. E. N. Willmer. Academic Press, London. 
Quinn, P. \& Wales, R. G. (1971) Fixation of carbon dioxide by preimplantation mouse embryos in vitro and the activities of enzymes involved in the process. Aust. F. biol. Sci. 24, 1277.

Quinn, P. \& WALEs, R. G. (1973a) The effect of culture in vitro on the levels of adenosine triphosphate in preimplantation mouse embryos. F. Reprod. Fert. 32, 231.

QuinN, P. \& WALEs, R. G. (1973b) The in vitro metabolism of $\left[\mathrm{U}_{-}{ }^{14} \mathrm{C}\right]$ glucose by the preimplantation rabbit embryo. Aust. F. biol. Sci. 26, 653.

WALEs, R. G. \& Biggers, J. D. (1968) The permeability of two- and eight-cell mouse embryos to L-malic acid. F. Reprod. Fert. 15, 103.

Wales, R. G., Quinn, P. \& Murdoch, R. N. (1969) The fixation of carbon dioxide by the eight-cell mouse embryo. F. Reprod. Fert. 20, 541.

Wales, R. G. \& Whittingham, D. G. (1970) Metabolism of specifically labelled pyruvate by mouse embryos during culture from the two-cell stage to blastocyst. Aust. 7. biol. Sci. $23,877$.

Wales, R. G. \& Whitringham, D. G. (1973) Development of eight-cell mouse embryos in substrate-free medium. F. Reprod. Fert. 32, 316 (Abstr.). 